\title{
Daily intake of palatable fluids presented to senescent and adult rats in a choice situation
}

\author{
JAMES R. MARTIN and ANDREAS FUCHS \\ E. Merck, Darmstadt, West Germany
}

\begin{abstract}
The relative intake of several palatable fluids presented simultaneously in a choice situation was evaluated in 16 senescent (31-33-month-old) and 16 adult (8-10-month-old) male rats in several 4 -day tests. In one test, water and $10 \%, 20 \%$, and $40 \%$ glucose solutions were presented; in another test, water and $0.03 \%, 0.06 \%$, and $0.12 \%$ sodium saccharin were given; and in a third test, rats were provided with water, $0.10 \%$ sodium saccharin, and $5 \%$ glucose for the 4-day test period. There was no appreciable age difference in the pattern of such long-term intake.
\end{abstract}

Numerous physiological, behavioral, and sensorimotor changes characterize senescence in the rodent (Campbell, Krauter, \& Wallace, 1980; Jänicke, Schulze, \& Coper, 1983; Marshall, 1982). In humans, decreased gustatory sensitivity occurs with aging (Cooper, Bilash, \& Zubek, 1959; Schiffman, 1979). However, the gustatory responsiveness of senescent rodents has received little attention despite considerable evidence for age-related alterations in peripheral gustatory organs, as well as in brain regions mediating taste (for review, see Schiffman \& Covey, 1984). In preference tests with water and saccharin solution present for a period of several days, it has been reported that the proportion of saccharin consumed was greater at 33 months of age than at 15 months for offspring of a noninjection control group of rats (Martin, Martin, Sigman, \& Day-Pfeiffer, 1983) and that senescent and young rats in a saline-injected control condition exhibited similar saccharin preferences (Ingram \& Peacock, 1980). Rats that began testing at 10-12 months of age showed a clear preference for saccharin over water throughout a 10-month period, with the amount of saccharin consumed at first decreasing but then returning to the initial level during the final months of evaluation (Strouthes, 1970). When given saccharin solution and water simultaneously for 15-30 min following fluid deprivation for 23-24 h, senescent and adult rats have been reported to show fairly similar saccharin preference (Ingram \& Peacock, 1980; Martinez \& Rigter, 1983). Guanowsky, Misanin, and Riccio (1983) found that fluiddeprived old rats drank an increasing proportion of saccharin solution relative to water in a two-bottle test as the test duration was increased from 0.5 to $24 \mathrm{~h}$, whereas the saccharin preference of young rats was stable throughout this interval. The present study was designed to further investigate the gustatory responsiveness of senescent and adult rats in 4-day tests with either several concen-

Send reprint requests to the first author at F. Hoffman-La Roche \& Co., Ltd., Pharmaceutical Research Division, Bldg. 72/119, Grenzacherstrasse 124, Basle 4002, Switzerland. trations of saccharin or several concentrations of glucose simultaneously available, or in a glucose-saccharin-water choice situation.

\section{METHOD}

The subjects were 16 senescent (31-33-month-old) and 16 adult (8-10-month-old) male Iva:SDIV rats obtained from Dr. Ivanovas Ges. für Versuchstierzuchten GmbH (Kisslegg, Allgaü, F.R.G.). The rats were transferred from SPF to conventional laboratory maintenance conditions at about 2-6 months of age. The animal quarters were maintained on a 12:12-h light-dark cycle. Pelleted laboratory chow (N-1324; Altromin Specialfutterwerke GmbH, Lage, F.R.G.) and tap water were continuously available in the home cage. Throughout the experiment, the rats were individually housed in Macrolon (Type III) cages with sawdust bedding. The ambient temperature of the animal quarters was about $23.5 \pm 1^{\circ} \mathrm{C}$.

The subjects were tested in their home cages. At the start of each 4day test, the rats were weighed. Then, three or four bottles with stainless steel spouts were attached to each cage. Fluid intake was measured each day on 4 consecutive days, with fresh solutions provided as necessary. Three different choice situations were evaluated in such 4-day tests, with the test order varied among subjects. The successive tests were separated by at least 1 week. At the time of daily measurement, the positions of the bottles were systematically varied. In one 4-day test, the rats received $10 \%, 20 \%$, and $40 \%$ d-glucose (E. Merck, Darmstadt, F.R.G.) and tap water. In another 4-day test, the rats received $0.03 \%$, $0.06 \%$, and $0.12 \%$ sodium saccharin (Sigma Chemical Co., St. Louis, MO) and tap water. In the third test situation, the subjects were given $5 \%$ glucose, $0.10 \%$ sodium saccharin, and tap water for a 4-day period. The glucose and sodium saccharin solutions were prepared with tap water. Fluid intake was measured to the nearest $0.1 \mathrm{~g}$.

\section{RESULTS}

Table 1 provides the absolute intakes of the various fluids presented in each of the three different choice situations. The senescent group drank $77 \%-88 \%$ of the total quantity consumed by the adult group across the three tests, although the mean body weight of the senescent rats was only $55 \%-63 \%$ of that of the adult rats at the start of these preference tests. There did not appear to be any appreciable age difference in the pattern of relative intake of the various glucose and saccharin solutions provided simultaneously in each of the choice situations.

In evaluating the intake for each individual rat, the 
Table 1

Four-Day Total Intake of Various Fluids Given Simultaneously in a Choice Paradigm

\begin{tabular}{|c|c|c|c|c|c|c|c|c|}
\hline \multirow[b]{2}{*}{ Test } & \multirow[b]{2}{*}{ Age } & \multirow[b]{2}{*}{$\mathrm{N}$} & \multirow{2}{*}{$\begin{array}{c}\text { Body } \\
\text { Weight }\end{array}$} & \multirow[b]{2}{*}{ Water } & \multicolumn{3}{|c|}{ Concentration* } & \multirow[b]{2}{*}{ Total } \\
\hline & & & & & A & B & $\mathrm{C}$ & \\
\hline \multirow[t]{2}{*}{ Glucose: } & Adult & 16 & $535 \pm 15$ & $\begin{array}{c}12.9 \pm 2.4 \\
(0)\end{array}$ & $\begin{array}{c}64.0 \pm 17.6 \\
(4)\end{array}$ & $\begin{array}{c}78.5 \pm 13.0 \\
(6)\end{array}$ & $\begin{array}{c}87.0 \pm 13.5 \\
(6)\end{array}$ & $242.4 \pm 18.9$ \\
\hline & Old & 15 & $338 \pm 10$ & $\begin{array}{l}16.4 \pm 6.1 \\
\text { (1) }\end{array}$ & $\begin{array}{c}34.9 \pm 8.7 \\
(3)\end{array}$ & $\begin{array}{l}66.5 \pm 17.5 \\
\text { (4) }\end{array}$ & $\begin{array}{c}69.7 \pm 9.4 \\
(7)\end{array}$ & $187.4 \pm 11.6$ \\
\hline \multirow[t]{2}{*}{ Saccharin: } & Adult & 16 & $543 \pm 14$ & $\begin{array}{c}20.2 \pm 5.8 \\
(3)\end{array}$ & $\begin{array}{c}17.1 \pm 4.2 \\
\text { (1) }\end{array}$ & $\begin{array}{c}37.3 \pm 13.6 \\
(3)\end{array}$ & $\begin{array}{c}141.1 \pm 22.4 \\
\text { (9) }\end{array}$ & $215.7 \pm 20.7$ \\
\hline & Old & 16 & $330 \pm 12$ & $\begin{array}{c}9.6 \pm 1.4 \\
(0)\end{array}$ & $\begin{array}{l}34.1 \pm 6.4 \\
\text { (1) }\end{array}$ & $\begin{array}{c}46.3 \pm 7.9 \\
(7)\end{array}$ & $\begin{array}{c}77.0 \pm 10.1 \\
(8)\end{array}$ & $167.0 \pm 8.4$ \\
\hline \multirow[t]{2}{*}{ Glucose vs. Saccharin: } & Adult & 15 & $609 \pm 13$ & $\begin{array}{c}20.0 \pm 7.8 \\
\text { (1) }\end{array}$ & $\begin{array}{c}42.6 \pm 12.3 \\
(1)\end{array}$ & $\begin{array}{c}225.8 \pm 34.7 \\
(13)\end{array}$ & & $288.4 \pm 31.1$ \\
\hline & Old & 15 & $334 \pm 11$ & $\begin{array}{c}9.5 \pm 1.6 \\
(0)\end{array}$ & $\begin{array}{c}49.4 \pm 13.1 \\
(2)\end{array}$ & $\begin{array}{c}195.5 \pm 28.2 \\
(13)\end{array}$ & & $254.4 \pm 24.7$ \\
\hline
\end{tabular}

Note -All intake values are given as mean grams \pm SEM, with the number of rats consuming the greatest volume of that particular fluid on at least 2 of the final 3 test days shown in the parentheses. $\quad{ }^{*}$ Concentrations of $A, B$, and $C$ were $10 \%, 20 \%$, and $40 \%$ for the Glucose test, $0.03 \%, 0.06 \%$, and $0.12 \%$ for the Saccharin test, and $0.10 \%$ sodium saccharin and $5 \%$ glucose for the Glucose vs. Saccharin test, respectively.

fluid of which the greatest quantity was consumed each test day was identified. The majority of subjects showed a relatively stable preference pattern, consuming most of the same concentration of a solution on two or more of the final 3 test days for a particular choice condition. There was a similar clear tendency for senescent and adult rats to preferentially consume the higher concentrations of glucose and saccharin and to prefer $5 \%$ glucose over both $0.10 \%$ sodium saccharin and water. However, in the test with water and several saccharin concentrations available, the senescent rats exhibited a more pronounced decline in consumption with decreasing concentration, whereas for adult rats the reduction in the amount consumed with decreasing saccharin concentration was much more gradual, with 3 of the 16 adult rats showing a preference for water on at least 2 of the final 3 test days. These results are also shown in Table 1.

One senescent rat died during the preference test with several glucose concentrations presented and before completing the glucose-saccharin-water test (a matched adult rat was excluded from further testing at this time). All other rats survived in good health for at least 1 week after the completion of the study.

\section{DISCUSSION}

No appreciable age differences in the pattern of chronic intake of either glucose or saccharin solutions of several concentrations given in choice tests were observed in the present study. However, the total fluid intake of the adult rats clearly exceeded that of the senescent rats, presumably due primarily to the greater mean body weight of the former group. Despite the sometimes very different experimental conditions, these results are generally consistent with those of previous studies that have shown, at most, small differences in chronic or acute saccharin intake calculated as a proportion of total water and saccharin solution intake for senescent and younger control rats (Guanowsky et al., 1983; Ingram \& Peacock, 1980; Martin et al., 1983; Martinez \& Rigter, 1983). The age at which the senescent rats were evaluated in the present study (31-33 months) exceeded the median survival age of this rat population, which has been estimated to be approximately 28 months. Thus, even in senescence, no obvious differences in the pattern of chronic intake of palatable fluids by rats were observed. It should be noted that in elderly humans gustatory function measured in tests involving suprathreshold stimuli has been found to be fairly normal (for review, see Stevens, Bartoshuk, \& Cain, 1984). The question of whether gustatory thresholds also remain relatively unaffected in senescent rodents was not addressed in the present study and has yet to be determined.

\section{REFERENCES}

Campbell, B. A., Krauter, E. E., \& Wallace, J. E. (1980). Animal models of aging: Sensory-motor and cognitive function in the aged rat. In D. G. Stein (Ed.), The psychobiology of aging: Problems and perspectives (pp. 201-226) Amsterdam: Elsevier/North-Holland.

CoOper, R. M., Bilash, I., \& ZubeK, J. P. (1959). The effect of age on taste sensitivity. Journal of Gerontology, 14, 56-58.

Guanowsky, V., Misanin, J. R., \& Riccio, D. C. (1983). Retention of conditioned taste aversion in weanling, adult, and old-age rats. Behavioral and Neural Biology, 37, 173-178.

Ingram, D. K., \& Peacock, L. J. (1980). Conditioned taste aversion as a function of age in mature male rats. Experimental Aging Research, 6, 113-123.

JäNICKE, B., SCHUlZE, G., \& COPER, H. (1983). Motor performance achievements in rats of different ages. Experimental Gerontology, 18, 393-407.

MarShall, J. F. (1982). Sensorimotor disturbance in the aging rodent. Journal of Gerontology, 37, 548-554.

Martin, J. C., Martin, D. C., Sigman, G., \& Day-Pfeiffer, H. (1983). Saccharin preferences in food deprived aging rats are altered as a function of perinatal drug exposure. Physiology \& Behavior, 30 , 853-858.

Martinez, J. L., JR., \& Rigter, H. (1983). Assessment of retention capacities in old rats. Behavioral and Neural Biology, 39, 181-191.

Schiffman, S. (1979). Changes of taste and smell with age: Psy- 
chophysiological aspects. In J. M. Ordy \& K. Brizzee (Eds.), Sensory systems and communication in the elderly: Vol. 10. Aging. (pp. 227-246). New York: Raven Press.

Schiffman, S. S., \& Covey, E. (1984). Changes in taste and smell with age: Nutritional aspects. In J. M. Ordy, D. Harman, \& R. Alfin-Slater (Eds.), Nutrition in gerontology (pp. 43-64). New York: Raven Press. Stevens, J. C., Bartoshuk, L. M., \& Cain, W. S. (1984). Chemi- cal senses and aging: Taste versus smell. Chemical Senses, 9, 167-179. Strouthes, A. (1970). Long-range two-choice saccharin and water consumption in rats. Journal of Comparative and Physiological Psychology, 73, 123-134.

(Manuscript received for publication October 29, 1984.) 